
and Allied Sciences (IJBPAS) 'A Bridge Betusen caboratory and Q Q nado'

Www.ibpas.com

\title{
EFFICACY OF KUNAPAJALA IN CONSERVATIVE CULTIVATION OF RAUVOLFIA SERPENTINE -A COMPARATIVE ORGANOLEPTIC, MICROSCOPIC AND PHYTOCHEMICAL STUDY
}

\author{
KRISHNAN PR ${ }^{1 *}$ AND MESHRAM $S^{2}$ \\ 1: Associate professor \& HOD Dept. of Dravyaguna Vignan PIAR, Parul University, \\ Vadodara, Gujarat, India
}

2: Professor Dept. of Dravyaguna Vignan PIAR, Parul University, Vadodara, Gujarat, India

*Corresponding Author: Dr Prasanth R Krishnan: E Mail: prasanth.r.krishnan@gmail.com

Received 12 ${ }^{\text {th }}$ Dec. 2021; Revised $14^{\text {th }}$ Jan. 2022; Accepted $7^{\text {th }}$ Feb. 2022; Available online $5^{\text {th }}$ March. 2022

https://doi.org/10.31032/IJBPAS/2022/11.3.1003

\begin{abstract}
Ever since Ayurveda attained world attention medicinal plants Scarcity turned out to be one among the prime lacunas in the research and development of ayurvedic medicines. It's a fact that we are lacking genuine drugs in the dry drug market because of unscientific drug collection and deforestation. So it's the need of the hour to start with scientific cultivation and conservative collection by rediscovering some of our ancient cultivation measures. Vrikshayurveda is a branch of Ayurveda where we can find enough references regarding the ancient cultivation techniques and different preparation techniques of natural manures one among them is kunapajala (organic liquid manure) so here in this research study we are assessing the efficacy of kunapajala in cultivation of Rauvolfia serpentina which is one among the red listed plants and is reported to be commonly adultered with R.tetraphylla.
\end{abstract}

Keywords: Kunapajala, Vruksha ayurveda, Organic farming, Sarpagantha, Histology

\section{\& Chemical analysis of Rauvolfia}

\section{INTRODUCTION}

If the scarcity of original drugs persists then we have to compromise the quality of our ayurvedic medicinal preparations which will definitely reflect in the clinical outcomes also. so we need to ensure maximum yield from the medicinal plant 
cultivations. For attaining the goal of maximum yield we have to rediscover such techniques which will not only increase the rate of production in medicinal plant cultivation but also it should increase the potency of medicinal plants. So here in this study we are accessing the efficacy of kunapajala an organic liquid manure explained in Surapala Nighantu on the cultivation of Rauvolfia serpentine ${ }^{1}$ The earliest references Of Vrukshayurveda can be traced from the Rigveda and Atharveda. The other books that provide valuable information are Kautilya's Arthasastra, Amarkosha, Krishi-Parashara and Varahmihir's Brhat Samhita etc. But no independent texts seem to have been written on the subject. The oral tradition however regarded Surpala's Vrikshayurveda as a credible compendium. ${ }^{2}$ Sadly the actual text of Surpala is not available. Surapala nighantu is a marvellous book in Ayurveda where we can see so many systematic techniques and guidance about vrukshayurveda in this book it mainly deals with cultivation and conservative collection of plants .one among them is nourishing therapy by ${ }^{3}$ Kunapajala. Kunapajala preparation technique is mentioned in this book and it is told that it acts as a good nourishing agent and a catalyst in growth and development of plant parts.

\section{METHODOLOGY}

\section{Method of collection of data}

We have identified and collected $1 \mathrm{~kg}$ of Rauvolfia serpentina seeds from Raairat gardens ,kerala and germinated according to standard cultivation protocol of Rauvolfia serpentina at parul institute of ayurved and research, Vadodara, Gujarat. After one month 60 healthy saplings were selected and planted in mud filled sacks for conservative cultivation in two different groups, For one group the standered cultivation protocol of Rauvolfia serpentina were followed, in one group normal water were be supplied once in two days but in group the second group along with normal water $60 \mathrm{ml}$ of kunapajal were supplied once in a month ${ }^{4}$

Duration- 2 years in this study two groups of saplings each were made by random selection method and the growth was allowed in same habitat and climatic conditions ${ }^{5}$.

Source of data Seeds of Rauvolfia serpentina from Raairat gardens, Kerala Sample size: 60 Group A (Study group): 30

Group B (Control group): 30

Trial drug: Rauvolfia serpentina with Kunnapajala

\section{ASSESSMENT CRITERIA:}

Pharmacognostic study

Organoleptic study

Microscopic study 
Physical comparison

Comparative analysis of phytochemicals in the roots of Rauvolfia serpentina of both the groups have been done after the harvest $^{6}$

Physical comparison in the roots of Rauvolfia serpentina of both the groups have been done after the harvest physical comparison of the roots done by weighing both the total yields separately from both the groups, after harvest have been done ${ }^{7}$

\section{RESULTS}

Organoleptic study (Table 1)

Microscopic study (Figure 1, 2)

Phytochemical study (Table 2)

Quantitative study (Table 2)

Table 1: Organoleptic study

\begin{tabular}{|c|c|c|c|}
\hline Sr. No. & Parameter & \multicolumn{2}{|c|}{ Observation } \\
\hline & & Test sample (Kunapajala sample) & Standard sample \\
\hline 1 & Color & $\begin{array}{c}\text { outer surface -yellowish to light } \\
\text { brown } \\
\text { Inner surface- pale yellowish white }\end{array}$ & $\begin{array}{c}\text { outer surface -greyish-yellow to light } \\
\text { brown } \\
\text { Inner surface - pale yellowish white }\end{array}$ \\
\hline 2 & Odour & indistinct & indistinct \\
\hline 3 & Size & $4-5 \mathrm{~cm}$ & $3-4 \mathrm{~cm}$ \\
\hline 4 & Taste & Bitter & Bitter \\
\hline 5 & Shape & Cylindrical & sub-cylindrical \\
\hline 6 & Surface & $\begin{array}{l}\text { Less rough with irregular } \\
\text { longitudinal fissures }\end{array}$ & $\begin{array}{l}\text { rough with irregular longitudinal } \\
\text { fissures }\end{array}$ \\
\hline 7 & Fracture & Short, irregular & Short, irregular \\
\hline 8 & Other features & Rootlets present & Rootlets absent \\
\hline
\end{tabular}

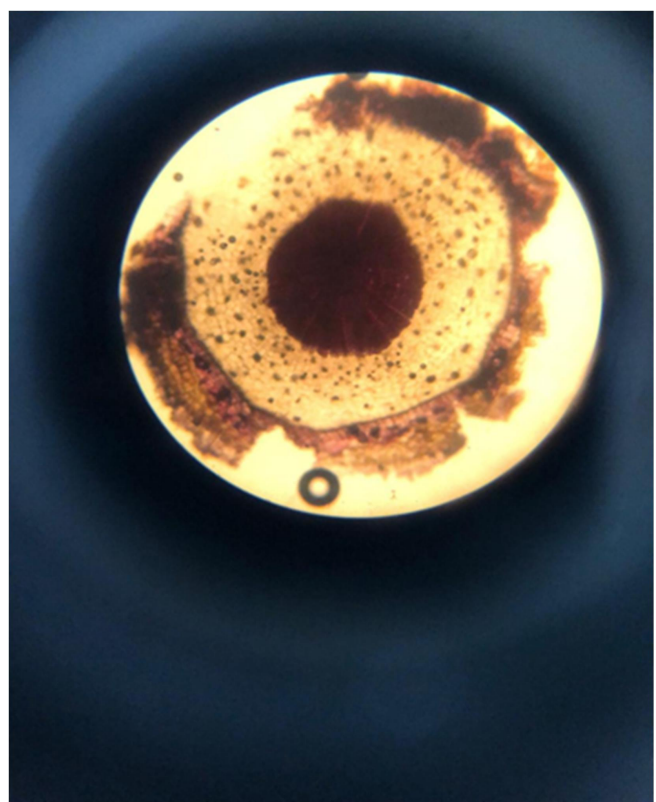

Figure 1: Standard sample of Rauwolfia A.T.S.of Rauwolfia root 


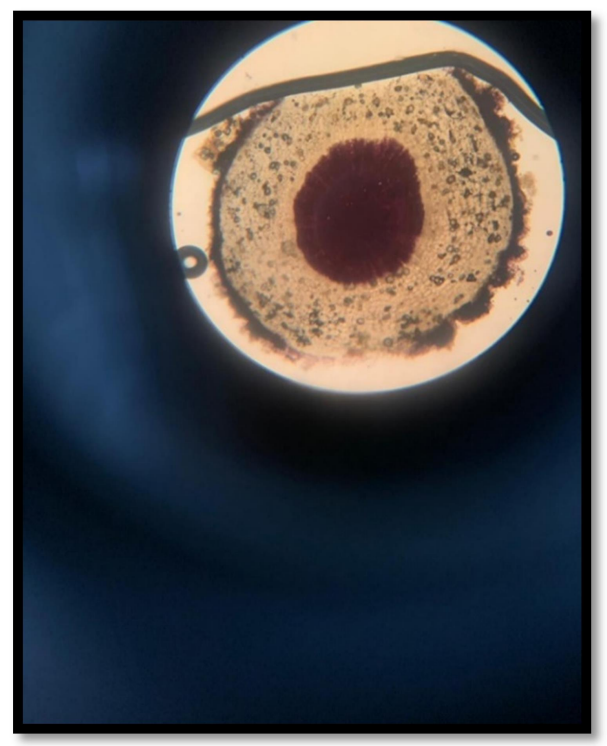

Figure 2: Test sample (Kunapajala sample)- Rauwolfia root B. T.S. of Test Sample (Kunapajala sample)

Table 2: Phytochemical study

\begin{tabular}{|c|c|c|c|}
\hline \multirow{2}{*}{ Sr.No. } & Phytochemical constituents & \multicolumn{2}{|c|}{ Qualitative analysis } \\
\cline { 3 - 4 } & Saponins & + & Test sample (Kunapajala sample) \\
\hline $\mathbf{1}$ & Flavonoids & + & + \\
\hline $\mathbf{3}$ & Steriods & + & + \\
\hline $\mathbf{n n y y}$ & Alkaloids & + & + \\
\hline $\mathbf{5}$ & Carbohydrates & + & + \\
\hline $\mathbf{6}$ & Proteins & + & + \\
\hline $\mathbf{7}$ & Terpenoids & - & - \\
\hline $\mathbf{8}$ & Cardiac glycosides & - & - \\
\hline $\mathbf{9}$ & Anthraquinines & - & \\
\hline
\end{tabular}

Table 3: Quantitative study

\begin{tabular}{|c|c|c|c|c|c|c|}
\hline Sr. No. & Phytochemicals & $\begin{array}{c}\text { Plant sample } \\
\text { taken }\end{array}$ & $\begin{array}{c}\text { Weight of extracted } \\
\text { plant constituents }\end{array}$ & \multicolumn{2}{|c|}{ Percentage content } \\
\hline & & & Test & Standard & Test & Standard \\
\hline 1 & Alkaloids & $5 \mathrm{gm}$ & $\mathbf{0 . 6 6 g m}$ & $\mathbf{0 . 6 1} \mathrm{gm}$ & $\mathbf{1 2 . 8 7}$ & 12.01 \\
\hline 2 & Saponins & $5 \mathrm{gm}$ & $\mathbf{0 . 3 6 g m}$ & $\mathbf{0 . 3 6 g m}$ & 1.82 & 1.82 \\
\hline 3 & Flavonoids & $5 \mathrm{gm}$ & $\mathbf{0 . 2 8 g m}$ & $\mathbf{0 . 2 8 g m}$ & $\mathbf{0 . 2 6}$ & 0.26 \\
\hline
\end{tabular}

\section{DISCUSSION}

\section{Organoleptic study}

While comparing the Organoleptic features of both the groups the Test sample (Kunapajala sample) Was having yellowish to light brown Color in the outer surface Where as the Inner surface were pale yellowish white in colour and the it was having indistinct Odour. The size of root was $5 \mathrm{~cm}$ and it was Bitter in taste. The specimen was Cylindrical in Shape the Surface where Less rough with irregular longitudinal fissures. On Fracture the sample shown Short, irregular pattern and rootlets where present in the specimen.

In the case of Standard sample it was having greyish-yellow to light brown in the outer surface Where as the Inner surface 
were pale yellowish white in colour and the it was having indistinct Odour . The size of root was $3-4 \mathrm{~cm}$ and it was Bitter in taste. The specimen was sub Cylindrical in Shape the Surface where rough with irregular longitudinal fissures.On Fracture the sample shown Short, irregular pattern and rootlets where absent in the specimen.

\section{Microscopic study}

Transverse section of root shows alternating rows of larger and smaller cork cells. The secondary cortex consists of several rows of tangentially elongated to isodiametric parenchymatous cells. These parenchymatous cells filled with starch grains and brown resin masses. The secondary xylem composed of vessels, tracheids, xylem parenchyma and xylem fibres traversed by xylem rays. It has one or more annual rings with a central dense core of wood. Cambium is indistinct, narrow, dark and wavering. The secondary phloem is consists of sieve cells, companion cells and rosette and prism type of crystals of calcium oxalate are present in parenchymatous cells. Some brown resin masses present in outer cells and contains phloem rays. Simple but compound granules of Starch grains are also present.

Transverse section of root shows alternating rows of larger and smaller cork cells but its narrow then the standard sample. The secondary cortex consists of several rows of tangentially elongated to isodiametric parenchymatous cells. These parenchymatous cells filled with starch grains in higher amount then the standard sample and brown resin masses. The secondary xylem composed of vessels, tracheids, xylem parenchyma and xylem fibres traversed by xylem rays. It has one or more annual rings with a central dense core of wood. Cambium is indistinct, narrow, dark and wavering. The secondary phloem is consists of sieve cells, companion cells and rosette and prism type of crystals of calcium oxalate are present in parenchymatous cells. Some brown resin masses present in outer cells and contains phloem rays. Simple but compound granules of Starch grains are also present.

\section{Phytochemical study}

In the phytochemical study we have conducted the test for Saponins,Flavonoids,Steriods,Alkaloids and in both the groups the test where positive

\section{Quantitative study}

Quantitative analysis of the alkaloids saponins and flavonoids of both the groups were done and compared . when we caompared the results of the quantitative analysis of the alkaloids saponins and flavonoids of both the groupsthe test group got $0.66 \mathrm{gm}, 0.36 \mathrm{gm}$ and $0.28 \mathrm{gm}$ of alkaloids saponins and flavonoids 
respectevely and the Standard group got $0.61 \mathrm{gm}, 0.36 \mathrm{gm}$ and $0.29 \mathrm{gm}$ of alkaloids saponins and flavonoids respectevely.that is if we take into consideration of the percentages of the result Alkaloidsin the Test group was $12.87 \%$ where as in the standered group was $12.01 \%$ and the percentage of Saponins when compared with the test group it was having 1.82 $\%$ content and the standered group also got the same Percentage content of Saponins and in the case of Flavonoids also both the group was having same Percentage content of Flavonoids that is $0.26 \%$

\section{CONCLUSION}

The comparison of microscopic study of the test and standard sample shows that the test sample contains narrow cork cells layer and abundant starch grains in secondary cortex layer. In the phytochemical study we have conducted the test for Saponins,Flavonoids,Steriods,Alkaloids and in both the groups the test where positive.that is not much difference is seen in that ,but when we caompared the results of the quantitative analysis of the alkaloids saponins and flavonoids of both the groupsthe test group got $0.66 \mathrm{gm}, 0.36 \mathrm{gm}$ and $0.28 \mathrm{gm}$ of alkaloids saponins and flavonoids respectevely and the Standard group got $0.61 \mathrm{gm}, 0.36 \mathrm{gm}$ and $0.29 \mathrm{gm}$ of alkaloids saponins and flavonoids respectevely.that is if we take into consideration of the percentages of the result Alkaloidsin the Test group was $12.87 \%$ where as in the standered group was $12.01 \%$ and the percentage of Saponins when compared with the test group it was having $1.82 \%$ content and the standered group also got the same Percentage content of Saponins and in the case of Flavonoids also both the group was having same Percentage content of Flavonoids that is $0.26 \%$. so the study can be concluded that the kunapajala can not only improve the yielsd but also it can improve chemical content of the cultivated drug,the improvement in the percentage of alkaloids there is an improvement of $0.86 \%$ as compared to the standerd drug

Funding -No funding was receaved from any organisation for this study

Conflit of interest -There was no conflit of interest arised during the study

\section{REFERENCES}

[1] Brajeshwar, A. K. Joshi and Subrata Dey (2007). Effect of kunapajala and fertilizers on senna (Cassia angustifolia Vakl.). Indian Forester, 1235-1240..

[2] Pandey A.K., Mandal A.K., Influence of propagation techniques and harvesting time on root yield and alkaloid contents of Rauvolfia serpentina , Journal of Natural Remedies, Vol. 10/1 (2010) 44 - 
49. [ cited 2015 Jan 10] Anuja, S. and P. Jayasri (2011). Effect of organic nutrients on flowering and herbage yield of sweet basil (Ocimum basilicum L.). Adv. Plant Sci., 24(II) : 601-603

[3] ShettyM.R.1, Harisha G A2, Jayanth Y 3, Kumar A Production of secondary metabolites from invitro cultures of Rauwolfia serpentina (L.) Benth., International Journal of Scientific Research Engineering \& Technology (IJSRET), Volume 2 Issue 12, March 2014, pp 844-852.

[4] Gill, B. S., R. S. Randhawa, G. S. Randhawa and J. Singh (1999). Response of turmeric (Curcuma longa L.) to nitrogen in relation to application of farmyard manure and straw mulch. J. Spices and Aromatic Crops, 8 : 211-14.

[5] Govindan, M. and R. R. Nair (1986). Azospirillum rhizocoensis in pepper. National seminar on Microbial Ecology, Jan 23- 24, TNAU, Coimbatore.

[6] Hemalatha, P., T. Suresh, T. Saraswathi and E. Vadivel (2008). Studies on nutrient content, herbage yield and alkaloid content of kalmegh under integrated nutrient management system. Adv. Pl. Sci., 21(II) : 447-451.

[7] Kalyanasundaram, $\quad$ B., $\quad$ T. Senthilkumar, S. Kumar and V. Swaminathan (2008). Influence of integrated nutrient management on yield, nutrient content, quality and economics of cultivation of sweet flag (Acorus calamus L.). Adv. P1. Sci., 21(I) : 277-280. 